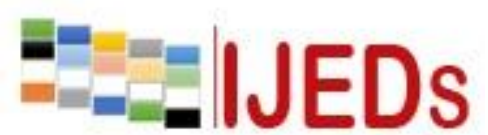

http://ijeds.ppj.unp.ac.id/index.php/IJEDS

\title{
APPLICATION OF STANDARD PROCESSES IN CLASS VISIT SUPERVISION TO IMPROVE TEACHER PERFORMANCE IN SDN 34 SANING BAKAR
}

\author{
*Eidmondi ${ }^{1}$, Farida $\mathbf{F}^{2}$ and Darmansyah ${ }^{2}$ \\ ${ }^{1}$ Basic Education Student, Postgraduate of Padang State University \\ ${ }^{2}$ Teachers of Basic Education Study Program, Postgraduate of Padang State \\ University \\ Email: chaniagoeidmond71@gmail.com
}

*Corresponding Author, Received: November 12, 2018, Revised: December 10, 2018, Accepted: December 21, 2018

\begin{abstract}
This research takes the form of school action research (PTS), which is the improvement of teacher performance with class visit techniques in order to implement standard processes, which consist of 2 cycles and each cycle consists of 4 stages: (1) action program planning stage, (2 ) implementation of action programs, (3) program observations, (4) reflection. Based on the research that has been done, it can be summarized as follows: Application of Class Visit supervision at SDN 34 Saning Bakar following the procedure based on the opinion of Sahertian (2000: 106) which is divided into four main steps namely: (1) planning (2) implementation and observation, (3) reflection There is an increase in the ability of class teachers at SDN 34 Saning Bakar after the implementation of supervision of class visits which initially only 30.17 , in the first cycle rose to 40.17, in the second cycle to 57.17 and in silus III to 74,50 . There was an increase in the ability to carry out classroom teacher learning at SDN 34 Saning Bakar after the implementation of class visit supervision from the initial value of 29.73 , in the first cycle rose to 44.33 in the second cycle rose to 55.33 and in the third cycle to 77.67 .
\end{abstract}

Keywords: Standard Process, Supervision of Class Visits, Teacher Performance

\section{INTRODUCTION}

The government in an effort to renew the national education system has established a vision, mission and national education development strategy. The vision of national education is the realization of the education system as a strong and authoritative social institution to empower all citizens of Indonesia to develop into quality human beings so that they are able and proactively to respond to the challenges of an ever changing era (Hermon and Dalim, 2005). 


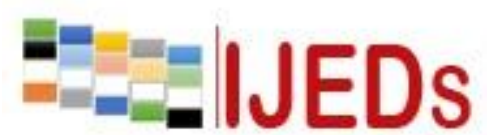

http://ijeds.ppj.unp.ac.id/index.php/IJEDS

\section{International Journal of Educational Dynamics}

Vol. 1 No. 1 (pp. 295-302) December 2018

p_ISSN 2655-4852

e_ISSN 2655-5093

Related to this vision, a set of principles for the implementation of education have been established to become the basis for implementing education reform. One of these principles is that education is held as a process of civilizing and empowering students that lasts a lifetime. In the process teachers need to provide exemplary, build willpower, and develop the potential and creativity of students (Hermon, 2015). The implication of this principle is the paradigm shift in the education process, namely from the teaching paradigm to the learning paradigm.

The process of interaction of students with teachers and learning resources in a learning environment. The learning process needs to be planned, implemented, assessed, and monitored so that it is carried out effectively and efficiently. The learning process in each primary and secondary education unit must be interactive, inspiring, fun, challenging, and motivating students to participate actively, and provide sufficient space for initiatives, creativity, and independence in accordance with the talents, interests, and physical and psychological development of participants student (Hermon, 2014).

Based on the National Education Ministerial Regulation, it can be seen that good learning needs to be designed in such a way that the implementation is really as expected. In order for the implementation of learning to be as desired, then the government establishes a standard on the implementation of learning called the Process Standard. Process standards are national education standards relating to the implementation of learning in educational units to achieve graduate competence. The process standard contains the minimum criteria for the learning process in primary and secondary education units throughout the legal territory of the Republic of Indonesia (NKRI). The standard of this process is a set of knowledge, skills, and behaviors that must be possessed, internalized, mastered and understood and actualized by the Teacher in carrying out his professional duties.

The standard learning process includes planning the learning process, implementing the learning process, evaluating learning outcomes, and supervising the learning process for the implementation of an effective and efficient learning process. In order for the teacher to show good performance in accordance with expectations, he 


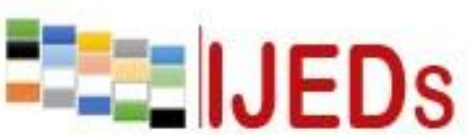

http://ijeds.ppj.unp.ac.id/index.php/IJEDS
International Journal of Educational Dynamics

Vol. 1 No. 1 (pp. 295-302) December 2018

p_ISSN 2655-4852

e_ISSN 2655-5093

must be able to carry out the standard learning process in accordance with Permendiknas No. 41 of 2007.

The teacher is one of the educational staff who has a role as a determinant of the success of educational goals, because the teacher directly interacts with students, to provide guidance that will produce the expected graduation. Teachers are human resources who become planners, actors and determinants of achieving organizational goals. Teachers are the backbone of educational activities, especially those related to learning activities. Without the ability, competence and role of the teacher, the teaching and learning process will be disrupted and even fail. Therefore, in the management of education, these three factors always improve their performance or performance, given the challenges of the education world to produce quality human resources that are able to compete in the global era.

According to Simamora (2010), performance is a certain requirement which ultimately can directly be reflected in the output produced both in the form of quantity and quality. The resulting output can be either physical or non-physical which calls it a work, namely a result / work in the form of physical / material or non-physical or nonmaterial. The teacher in doing his job well, is often determined by an assessment of his performance. Assessment is not only done to help oversee organizational resources but also to measure the level of efficiency of the use of existing resources and identify things that need to be improved. Assessment of performance is an important factor to improve teacher work performance and satisfaction, the parts that show the teacher's abilities that are less identifiable, are known so that strategies can be determined in improving their performance.

The role of the teacher is very decisive in efforts to improve the quality of formal education. For that teachers as agents of learning are required to be able to carry out the learning process as well as possible, within the framework of educational development. The teacher has a very strategic function and role in the development of the education sector, therefore it needs to be developed as a dignified profession. Another problem that the authors found in SDN 34 Saning Bakar District X Koto Singkarak is first, the weakening role of teachers in delivering students to achieve achievements in certain events. So that the teacher in improving student achievement 


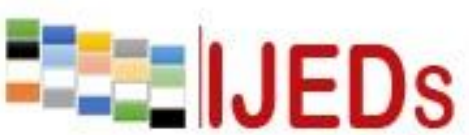

http://ijeds.ppj.unp.ac.id/index.php/IJEDS
International Journal of Educational Dynamics

Vol. 1 No. 1 (pp. 295-302) December 2018

p_ISSN 2655-4852

e_ISSN 2655-5093

tends to decline, sometimes even without targets, which is important to carry out the tasks of the leadership. Second is the performance of the teachers of SDN 34 Saning Bakar Subdistrict $\mathrm{X}$ Koto Singkarak including not showing the professional competence of an educator, this can be seen from the discipline of teachers who often leave class hours for certain reasons, for example working on additional assignments is not the main task or teacher.

\section{METHOD}

This research will be carried out in the Public Elementary School 34 Saning Bakar District X Koto Singkarak, Solok Regency. The author chose this school as a place of research with the consideration that: (1) this school is the place where writers carry out their daily tasks, (2) Based on the observations of the author, academic supervision has not been implemented properly and has not been able to contribute to the teacher's ability to implement process standards. The research subjects were all teachers at SDN 34 Saning Bakar 2015/2016 academic year which numbered 10 people consisting of: class 6 teachers, sports teacher 1 PAI teacher 1 person and 2 people gracious teachers. The time to take action is in the January-June 2015/2016 semester, which is planned to be carried out in two cycles. Duration of study 3 months from planning to writing research reports.

\section{RESULTS AND DISCUSSION}

Supervision activities are used to advance learning through the growth of teacher abilities. Supervision according to Karwati (2013), will encourage teachers to be more empowered, and the learning situation to be better, effective and the emergence of satisfaction in the teacher after implementing it. The principal as the supervising implementer must be able to guide the teachers he leads efficiently who can instill trust, stimulate, and the ability to assist teachers in solving problems they face and be able to conduct professional coaching in order to improve teaching quality and quality of learning.

The implementation of good supervision is strongly influenced by the accuracy of the techniques used by the supervisor. Supervision techniques are divided 


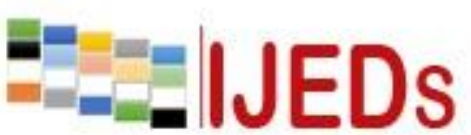

http://ijeds.ppj.unp.ac.id/index.php/IJEDS
International Journal of Educational Dynamics

Vol. 1 No. 1 (pp. 295-302) December 2018

p_ISSN 2655-4852

e_ISSN 2655-5093

into two types, namely individuals and groups. Supervision of group techniques according to Karwati (2013: 221) is a technique of supervision carried out by the principal when facing many teachers who face the same problem.

There have been several improvements after the supervision of class visits was carried out: (1) An increase in the ability of class teachers at SDN 34 Saning Bakar after the implementation of supervision of class visits was initially only 30.17 , in the first cycle rose to 40.17, in the second cycle to 57.17 and in silus III to 74.50 , (2) Increased ability to carry out classroom teacher learning at SDN 34 Saning Bakar after the implementation of class visit supervision from the initial value of 29.73 , in the first cycle rose to 44.33 in the second cycle rose to 55.33 and in the third cycle to 77.67 , (3) Teachers are a key element in the education system, especially in schools. All other components, starting from the curriculum, facilities, costs, etc. will not mean much if the essence of learning is the interaction of teachers with students who are not qualified. All other components, especially the curriculum will be "alive" if implemented by the teacher.

Many experts stated that at school there would be no change or improvement in quality without change and improvement in the quality of teachers. Unfortunately, in the culture of Indonesian society until now the work of the teacher is still quite closed, even the supervisor of the teacher such as the principal and supervisor is not easy to obtain data and observe the daily reality of the teacher's performance in front of students. Indeed the class visit program by the principal or supervisor is impossible to be rejected by the teacher, but it is not uncommon for the teacher to try to show his best performance both in the aspects of planning and learning only when visited, then he will return to work as usual, sometimes without preparation mature and without enthusiasm and high enthusiasm.

The presence of Government Regulation Number 19 of 2005 concerning National Standards of Education is an important milestone towards standardized education. In the Government Regulation it is stated that the National Education Standards are the minimum criteria regarding the education system in all jurisdictions of the Unitary State of the Republic of Indonesia, with a scope of 8 standards, namely: (1) Standard content; (2) Process standards; (3) Graduate Competency Standards; (4). 


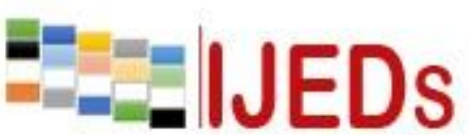

http://ijeds.ppj.unp.ac.id/index.php/IJEDS
International Journal of Educational Dynamics

Vol. 1 No. 1 (pp. 295-302) December 2018

p_ISSN 2655-4852

e_ISSN 2655-5093

Standards of Educators and education staff; (5) Standard Facilities and infrastructure; (6) Management Standards; (7) Financing standards and; (8) Educational Assessment Standards.

In planning the learning process in accordance with Permendiknas No. 41 of 2007, all teachers are required to prepare syllabi and Learning Implementation Plans (RPP). The teacher has indeed designed the learning plan in the form of syllabus and lesson plans, but what often happens in the environment of SDN 34 Saning Bakar District X Koto Singkarak in making syllabus and Learning Implementation Plans (RPP) is still done in groups through the cluster level Teacher Working Group (KKG) . Considering the making together, there are some active and some passive teachers, who have not fully realized the duties and responsibilities they carry, so their obligations are often overlooked, in the planning of learning that is making RPP, teachers just copy (copy paste) RPP from previous years. Teachers who passively make lesson plans are only to fulfill administrative obligations, not for reference in carrying out learning in class, so that the implementation of learning in the classroom is relatively unplanned, as a result the learning outcomes achieved by students are not encouraging.

In the implementation of learning, there are teachers who still apply the method of recording the lesson to completion or giving the task of completing the practice questions then leaving the class until the lesson is finished, so that the classroom atmosphere is not conducive because the teacher is not present without any clear reason. In fact, students often leave the class because the teacher is not there and the teacher does not instill discipline values with students. In terms of assessment, teachers sometimes rely solely on feelings not based on the actual learning outcomes of children so that it can be said in the assessment that they have not applied consistent and systematic principles.

This phenomenon is very worrying because from this phenomenon it can be assumed that the performance of the teachers of SDN 34 Saning Bakar District X Koto Singkarak has not been optimal in carrying out the standard process in accordance with Minister of National Education Number 41 of 2007, so the author tries to examine the phenomena that occur in 34 Saning Elementary School teachers Burning District X Koto Singkarak is especially in implementing the standard process. Besides that the 


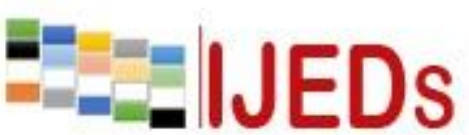

http://ijeds.ppj.unp.ac.id/index.php/IJEDS
International Journal of Educational Dynamics

Vol. 1 No. 1 (pp. 295-302) December 2018

p_ISSN 2655-4852

e_ISSN 2655-5093

weakening of teacher performance can be seen, among others, the symptoms of teachers who often absent / absenteeism in teaching, teachers who enter classes who are not on time or late in entering school, teachers who teach do not have teaching preparation or incomplete teaching preparation.

The task of the teacher who is routine in teaching and learning shows the phenomenon that the teacher teaches only a routine without any further development innovations, even the existence of several concepts of active learning models are still rarely applied, because active learning methods are less attractive to them. The principle by some teachers says that the important teaching and learning activities are in accordance with the job and the hours he has fulfilled are enough for them. The teacher's role is still lacking to deliver high achieving students, he is only a teacher who is in charge of teaching and then gets a salary / salary without regard to other aspects of education, such as providing guidance to students, developing student talents, not running remedial programs and enrichment regularly.

\section{CONCLUSION}

Application of Class Visit supervision at SDN 34 Saning Bakar follows the procedure based on the opinion of Sahertian (2000: 106) which is divided into four main steps namely: (1) planning (2) implementation and observation, (3) reflection. An increase in the ability of class teachers at SDN 34 Saning Bakar after the implementation of supervision of class visits was initially only 30.17 , in the first cycle rose to 40.17 , in the second cycle to 57.17 and in silus III to 74.50. Increased ability to carry out classroom teacher learning at SDN 34 Saning Bakar after the implementation of class visit supervision from the initial value of 29.73 , in the first cycle rose to 44.33 in the second cycle rose to 55.33 and in the third cycle to 77.67 .

\section{REFERENCES}

Akdon. 2006. Strategic Management for Educational Management, Bandung: Alfabeta.

Arikunto, Suharsimi. 2009. Dasar- Dasar Supervisi. Jakarta: Rineka Cipta 


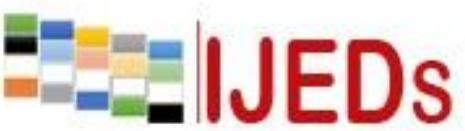

http://ijeds.ppj.unp.ac.id/index.php/IJEDS
International Journal of Educational Dynamics

Vol. 1 No. 1 (pp. 295-302) December 2018

p_ISSN 2655-4852

e_ISSN 2655-5093

Aunurrahman. 2009. Belajar dan Pembelajaran. Bandung: Alfabeta. Baharuddin. 2010. Teori Belajar dan Pembelajaran. Jogjakarta: Arruz Media.

Drucker, Peter F. 2005. Manajemen: Tugas dan Tanggung jawab, praktek. Jakarta: Gramedia Pustaka Utama.

Glickman. 2007. Tujuan Supervisi. Bandung: PT Remaja Rosdakarya

Hamalik, Oemar. 2008. Perencanaan Pengajaran Berdasarkan Pendekatan Sistem. Jakarta: Bumi Aksara.

Hasibuan, Malayu S.P.H. 2005. Manajemen Sumber Daya Manusia. Edisi revisi. Jakarta: Bumi Aksara.

Hamza B. Uno. 2010. Model Pembelajaran, Jakarta: Bumi Aksara

Hermon, D and Y. Dalim. 2005. Penggunaan Media Audio Visual untuk Meningkatkan Kreatifitas Belajar. Jurnal Pembelajaran 28 (3), 266-276.

Hermon, D. 2014. Desain Kebijakan Tanggap Darurat dan Pemulihan Bencana Letusan Gunung Sinabung. Seminar Nasional Geografi. Master Program of Geography Education, Universitas Negeri Padang.

Hermon, D. 2015. Arahan Kebijakan Keberlanjutan Pendidikan 10 Tahun Pasca Bencana Tsunami di Kabupaten Aceh Jaya Provinsi Aceh. Seminar Nasional Geografi. Master Program of Geography Education, Universitas Negeri Padang.

Indah Kosmiyah. 2012. Belajar dan Pembelajaran. Yogyakarta: Teras.

Mulyasa E.2005. Menjadi Kepala Sekolah Profesional. Bandung:Remaja Rosda Karya.

Mulyadi. 2007. Sistem Perencanaan dan Pengendalian Manajemen (edisi.3) .Jakarta: Salemba Empat.

Peraturan Menteri Pendidikan Nasional No. 19 tahun 2005 tentang Standar Proses untuk Satuan Pendidikan Dasar dan Menengah.

Peraturan Menteri Pendidikan Nasional No. 41 tahun 2007 tentang Standar Proses untuk Satuan Pendidikan Dasar dan Menengah

Sahertian, Piet.A. 2000. Konsep Dasar \& Teknik Supervisi Pendidikan dalam Rangka Pengembangan Sumber Daya Manusia. Jakarta. Rineka Cipta.

Sardiman AM. 2005. Interaksi dan Motivasi Belajar Mengajar. Jakarta: CV.Rajawali.

Sukiman. 2012. Pengembangan Media Pembelajaran. Jogjakarta: Pedagogia.

Simamora, Henry. 2006. Manajemen Sumber Daya Manusia, Yogjakarta: STIE YKPN.

Slameto.2010. Belajar dan Faktor-faktor yang Mempengaruhinya. Jakarta: PT. Rineka Cipta.

Trianto. 2009. Mendesain Model Pembelajaran Inovatif-Progresif. Jakarta: Kencana.

Undang-Undang Republik Indonesia Nomor 20 Tahun 2003 (Edisi 2009), Tentang Sistem Pendidikan Nasional, Bandung, Depdiknas, Citra Umbara. 